\title{
TTR
}

Traduction, terminologie, rédaction

\section{Translation North and South: Composing the Translator's Archive}

\section{María Constanza Guzmán}

Volume 26, numéro 2, 2e semestre 2013

Traduction et conscience sociale. Autour de la pensée de Daniel Simeoni

Translation as Social Conscience. Around the Work of Daniel Simeoni

URI : https://id.erudit.org/iderudit/1037136ar

DOI : https://doi.org/10.7202/1037136ar

Aller au sommaire du numéro

Éditeur(s)

Association canadienne de traductologie

ISSN

0835-8443 (imprimé)

1708-2188 (numérique)

Découvrir la revue

Citer cet article

Guzmán, M. C. (2013). Translation North and South: Composing the Translator's Archive. TTR, 26(2), 171-191. https://doi.org/10.7202/1037136ar

\section{Résumé de l'article}

L'une des plus importantes contributions de Daniel Simeoni à la traductologie réside dans son exploration des traducteurs en tant qu'agents de production culturelle. Cette conception prend sa source, selon Simeoni, dans une conscience vive de l'ancrage social et géopolitique de ces derniers. Dans cette perspective, et suivant plus particulièrement l'appel de Simeoni à l'élaboration de « sociographies » de traducteurs, le présent article développe la notion d'" archives de traducteurs ". Il explore en quoi cette catégorie épistémologique et méthodologique permet de mieux comprendre l'agent traduisant, en constituant une généalogie de sa praxis. L’auteure applique plus précisément cette notion à l'étude de la position sociale et de l'agentivité des traducteurs et traductrices littéraires oeuvrant dans le contexte des Amériques. 


\title{
Translation North and South: Composing the Translator's Archive
}

\author{
María Constanza Guzmán \\ Glendon College, York University
}

\begin{abstract}
One of Daniel Simeoni's major contributions to translation thinking is his investigation of the translator as an agent of cultural production. This approach to the translator, in Simeoni's view, originates in a strong sense of social and geopolitical situatedness. Based on this perspective and drawing on Simeoni's arguments and in particular on his call to develop translators' "sociographies," in this paper I posit the notion of the "translator's archive" as an epistemological and methodological possibility to study the translator and for a geneology of translation praxis. I investigate the significance of the "translator's archive" in particular to understand the place of literary translators and their social situatedness and agency in the context of the Americas.
\end{abstract}

Keywords: Latin American narratives, US translators, translator's sociography, literary translation, translator's documents, translator's archive

\section{Résumé}

L'une des plus importantes contributions de Daniel Simeoni à la traductologie réside dans son exploration des traducteurs en tant qu'agents de production culturelle. Cette conception prend sa source, selon Simeoni, dans une conscience vive de l'ancrage social et géopolitique de ces derniers. Dans cette perspective, et suivant plus particulièrement l'appel de Simeoni à l'élaboration de "sociographies» de traducteurs, le présent article développe la notion d'«archives de traducteurs». Il explore en quoi cette catégorie épistémologique et méthodologique permet de mieux comprendre l'agent traduisant, en constituant une généalogie de sa praxis. L'auteure applique plus précisément cette notion à l'étude de la position sociale et de l'agentivité des traducteurs et traductrices littéraires œuvrant dans le contexte des Amériques.

Mots-clés: récits latino-américains, traducteurs nord-américains, sociographie de traducteur, documents sur le traducteur, archives de traducteurs 
The image of Latin American literature beyond languagebound national literatures is constructed, to a large extent, in and through translation. As they become decontextualized from their local traditions, translated narratives enter in relation with other forms of discourse. Translators are responsible for the traveling of narratives across languages and territories. Translation is thus part of a continuum of cultural production where the translator plays a key role as a social agent. Besides the fact that literary translations have traditionally been studied as detached from the subject who translates, as if they were unmediated renditions of an author's work and of her or his consciousness, and perhaps also as a result of this perception, the translator's presence and her work are not part of the map of literature as it is conventionally constructed in literary studies. ${ }^{1}$ This leaves minimal space to render translators as a presence and grant them a discursive space.

This article is part of a larger project entitled Voces de traductores/Translators' Voices, which has aimed to investigate the role of US translators of Latin American literature as agents in the construction of a Latin American imaginary. I have placed translators at the centre of this enquiry and characterized them as key agents to understand the way in which Latin American narratives travel from the south to the north and beyond. I aim to articulate a critical historiographic approach to study the global circulation of Latin American narratives.

\section{Outlining Translators' Sociographies}

This article focuses on some of the conceptual and methodological aspects of the project. I draw on Daniel Simeoni's articulations of the translator as agent and on his call for the need of translator's "sociographies" (Simeoni, 1998, p. 31), in order to introduce the notion of the "translator's archive" as a conceptual space that allows for a coherent examination of the translator's work, self, and self-understanding. I frame and explain the translator's archive as a composition of the translations themselves, of other writing products and practices, as well as of the translator's biography. The translator's archive comprises diverse elements of the intellectual and personal history of each individual translator. I illustrate the argument mentioning some of the ways

1. I discuss this question in the first chapter of Gregory Rabassa's Latin American Literature: A Translator's Visible Legacy (Guzmán, 2010). 
in which I engage translator's archives to investigate translators' views and understandings of their practice, the views on writing and textuality that inform their articulations of it, and their characterizations of their own image as cultural agents. The examination of the translator's archive is key to understanding the place of literary translators and their social situatedness and agency at large, and in the context of the Americas in particular. It sheds light on the material and symbolic conditions of the production and reterritorialization of narratives, the formation of canons, and the discursive construction of global collective images.

One of Daniel Simeoni's major contributions to translation thinking, as can be seen in articles such as "Translating and Studying Translation: The View from the Agent" (1995) and "Between Sociology and History: Method in Context and in Practice" (2007a) is his call for the study of the translator as an agent of cultural production. Such an approach to the translator requires a strong sense of social and geopolitical situatedness. It goes beyond the individual to include historical and social considerations. Through his ongoing epistemological and methodological reflection, Simeoni stresses the need to develop the "sociological eye" in translation studies, a field in which, in his view, "the social was always backstage, peripheral to questions of textual quality, authorship, or commission"; he underscores the importance of "moving from a predominantly linguistic/semiotic outlook towards a broader, 'contextualizing' comprehension not only of translation but of all textual production" (Simeoni, 2007b, pp. 14-15). Simeoni offers a critique of deterministic sociological frameworks and a serious and considered exploration of the possibilities that sociological perspectives can offer, from an interdisciplinary, non-restrictive perspective, as "a global retreat from the linguistic, text-exclusive paradigm" (ibid., p. 16).

Particularly in the last decade, and owing a great deal to Simeoni's own disciplinary explorations, the possibilities of the interface between translational and sociological phenomena have been studied in greater depth. As Michaela Wolf indicates, Simeoni's sociological approach corresponds to the "sociology of agents," focusing on theories that bring social action to the fore and conceive of social life from the perspective of individually acting persons who are involved in social processes (Wolf, 2007, 
p.14). Simeoni describes conventional views of translators as social agents as follows:

Translators as social agents are perceived today anywhere along a continuum of practice marked by varying degrees of agency. Either they are seen as norm-carriers alternating between the (rarely) innovative and the (often) perpetuating, or they are described as failed producers, relegated to the lowest rung on a scale of visibility. (Simeoni, 2007a, pp. 201-202)

Simeoni's view of the agent is clearly rooted both in the social structures and at personal, intimate, and unconscious levels, and includes not only detached participation of the subject or agent who translates, but her/his "involvement" (Simeoni, 1995, pp. 448-452). ${ }^{2}$

For Simeoni, the notion of the translator as agent developed largely around Pierre Bourdieu's notion of "habitus," more specifically of the translator's habitus, whereby the translator is understood as both a (culturally) pre-structured and a structuring agent mediating cultural artifacts in the course of transfer/ translation. ${ }^{3}$ Simeoni developed this idea aiming to understand questions of "translatorial competence" and for a genealogy of the translator's self-definition (1998, p. 1). He finds in the translator's habitus a space, beyond the strictly textual, to problematize ideas associated with the translator's secondariness and subservience (ibid., p. 7). He grants special importance to the question of the translator's self-image:

2. It is worth noting that, in his formulation of the translator as agent, Simeoni discusses the difference between the notions of "subject" and "agent"-between which he fluctuated. He specifies this difference as follows: "I will simply say that the 'agent' is the 'subject' but socialized" (Simeoni, 1995, p. 452). He points out that to speak of a translating agent suggests that "the reference is a voice, or a pen (more likely a computer today), inextricably linked to networks of other social agents. Besides, unlike the 'subject', the 'agent' may be conceived of as instituted' (ibid.). Moreover, Simeoni extends his reflection of the translator as agent to the agency of the translation researcher.

3. Simeoni's use of the notion of habitus as well as its applicability for translation studies have been widely documented, and it is not within the scope of this paper to elaborate on this matter in great depth. For references, see Constructing a Sociology of Translation (2007). 
[...] it is not so much the activity of translating, nor the translator himself, nor objective norms as such, but the internalized position of the translator in his field of practice which may turn out to be the single most determining factor. For historical reasons turned structural, this position has been consistently relegated backstage. (ibid., p. 12)

Simeoni characterizes such subservient attitude as both cause and effect of the low prestige and secondariness of translation in the social field. He points out the difficulty to establish the boundaries of the translator's habitus, which occurs whenever agents straddle different fields, "either within a single culture, or even more so, across cultures" (ibid., p. 20). He imagines the translator's habitus as "an assemblage of sorts," dynamic, unstable, expressive of the interplay of multiple kinds of habitus-specific, cultural and economic, social and state-national, and characterizes it as "the elaborate result of a personalized social and cultural history" (ibid., p. 32). This is part of the basis for his definition of translation as "the quintessential activity of a cultural mind moulded by the social environment and incorporated in the translator's act" (ibid.).

Simeoni's concern with the social and structural forces that condition translators' practices shows his recognition of the urgency for an informed, epistemological critique of the translator's role, mission and status in the present global order. His definition of the translator's habitus gives strength to the idea of the translator as a social and cultural agent, partly by specifying the special cultural capital required for the task but also positioning the translator among other types of agents. Simeoni is careful in defining translation as a form of writing, the products of which are the results of diversely distributed social habituses or specific habituses governed by the rules pertaining to the field in which the translation takes place (1998, p. 19). Viewed as agents, translators are not only invested cultural mediators "bridging" cultures as abstract constructs devoid of social specificity, but exist within a social landscape that conditions their performance. The translator's performance, in turn, is a form of social action that can be studied among other forms of social action whose relation with translation may not otherwise be apparent.

One of Simeoni's concerns in regard to the intersection between translation and the social sciences was that of how to deal with questions of method. In particular, his later work searched 
for methodological possibilities in socio-historical case studies in order "to locate an interdisciplinary space where a socio-translation studies could establish itself" (2007a, p. 187). He proposed a method that, despite being part of "a body of scholarly practices, inherited-consciously or not-from the traditional disciplines" and their tensions $[\ldots]$ could be fluid and inclusive, "necessarily critical of previous disciplinary formations" (ibid., p. 189). Simeoni proposes translation as a

cognitive "operator" [...] a mechanism which provides
access to the social worldview in a "double sense," first
as a necessary condition for the ordinary, day to day
comprehension that we have of the social world around
us, in our daily exchanges with others, and secondly, as
a prerequisite for scholarly interpretations of the social
world. (2007b, p. 26)

The social, for Simeoni, is populated with doubt and uncertainty. His view of method is informed by his recognition that translation and its study belong to the "troubling," "intermediate zone" of "blurred borders," which is one of the reasons why, as he notes, it has not always been possible to discuss the various dimensions of the link between translation and society including "the role played by translations and translating in society, on the social dimension of the practice, the interplay of the complex social forces shaping the politics of translation worldwide, or on the history of these interrelations" (ibid., p. 13).

In discussing future research directions, Simeoni suggested the use of flexible models to come up with multiple sociosymbolic interpretations of the translator's task. The conceptual elaboration I develop in this article is based, in part, on Simeoni's call for modern "sociographies of single translators' professional trajectories" which he felt are lacking. He proposed carrying out this type of project through interviews or biographical research (1998, p. 31). ${ }^{4}$ At the end of "The Pivotal Status of the Translator's Habitus," and in his characteristically dialogical way of writing, Simeoni made the call for translator's sociographies as an

4. Simeoni specified that for such a sociography to take shape no complicated apparatus of "sample-based techniques" is required; he suggests biographical research as "legitimate area of social science whose findings can be solicited" (1998, p. 31). 
invitation, as an epistemological and methodological possibility, rather than a fully developed and worked-out characterization of what such a "sociography" would look like.

Simeoni's emphasis on contextualizing translators in terms of their historicity and position in the cultural sphere, his proposal to carry out translators' sociographies, and his urgent call to think of the question of method for socio-historical approaches to translation praxis, inspired me to reflect on my research on translators of Latin American literature from this perspective. The idea of a translator's sociography quickly proved to be a rich and open territory, suggestive of new research questions. I now see my investigation of translation in the Americas partly as a project of outlining sociographies of North American translators of Latin American literature based on a fluid approach to a critical historiography. Through this lens, I have been able to consider the role of English translators of Latin American authors in the second half of the twentieth century in light of their individual agency and subjectivity in a continuum regulated by the social, including various aspects that may constitute their babitus. This enables me to examine their legacy from the point of view of the agent, going beyond strictly aesthetic considerations to question how structural forces participate in the formation of literary canons and in the selection, production, diffusion, and reception of works in translation. I also feel compelled to locate myself as the researcher-agent whose gaze can be framed, questioned, opened to alternative perspectives, and whose epistemological choices may respond to unstated and unconscious motivations.

\section{Toward the Translator's Archive}

A translator's sociography includes the translator's biography and goes beyond it. Methodologically, research for a translator's sociography may involve archival research and other methods of historiography. It may also involve conducting interviews or doing other types of data collection which are more characteristic of ethnographic work - such as participant observation or interviews with translators, authors, publishers, and others. ${ }^{5}$ As such, the research for a translator's sociography entails a documenting

5. For an illuminating discussion on the relationship between translation and ethnography as practices of knowledge production see Buzelin's work (2007). 
process that involves searching for and working with materials that exist but which may not be readily available or classified, such as the translator's works and documents-these range from the translations themselves to prefaces, various types of paratexts, and published and unpublished texts. In addition, outlining a translator's sociography will include information that is not produced, or authored, by the translator, information which may not necessarily exist in text form (e.g., biographical data). Moreover, doing translators' sociographies will entail not only the search but the production of texts that will come out of the research process. ${ }^{6}$ The analysis will involve an examination of a myriad of materials, textual and otherwise, necessary for a critical discussion of the perceptions translators themselves have of their work and their views about language and culture contact. A sociography is an examination of the translator's history and also of the translator's "stories" or "narratives," which also entails the observation of the context in which translation is practiced. ${ }^{7}$ This examination involves the relationship between the social and political realms and the intimate and subjective, within translating events that are situated in particular social geographies.

As I consider the translator's statements as part of the translator's body of works, throughout my project looking at translator's voices and both before and after framing it in terms of translators' sociographies, I have worked with various kinds of translator's texts. Looking at the translator's written documents and searching for and documenting the sources where the translator's views and perceptions can be traced, I found myself amidst a multiplicity of materials which, albeit their richness, are often difficult to tackle. The process of searching for these documents is an archeology of sorts which, to become meaningful (instead of being a mere sum of documents retrieved)

6. E.g., a researcher may have to create or compose a narrative of a translator's life or of her or his translation praxis on the basis of scattered information or of accounts that focus on writers and/or works, not on the subject who translates, and which need to be reframed for the purpose of the translator's sociography.

7. I base this understanding of "story" or "narrative" in part on Baker's definition of narratives as the "public and personal stories that we subscribe to and that guide our behaviour" (2006, p. 19). They are, she states, "the stories we tell ourselves, not just those we explicitly tell other people, about the world(s) in which we live" (ibid.). 
requires direction and critical texture and substance. I argue that the "archive," and more specifically the notion of the "translator's archive," is a suitable operational notion to designate such a collection of variegated materials. ${ }^{8}$

In its most strict sense, the "translator's archive" is a repository of translator's texts and statements. On the one hand, although relatively rare, there exist physical spaces that serve as translator's archives as such. ${ }^{9}$ Whether or not the translator's texts are physically in one place or scattered and disperse, there is a materiality to the archive in that it includes written documents; these include articles, interviews, and other accounts of the translator's own work, as well as prefaces, footnotes, annotated drafts and manuscripts, marginalia, correspondence with authors and editors, notes, notebooks, and so on. Along with the translator's body of works (i.e., the translations themselves as well as other writings), these documents are a fundamental part of the translator's archive.

On the other hand, the translator's archive as a concept is a more complex composition that is not limited to the archive's materiality, to translator's written statements, but which includes translators' biographies, their practices, the agents involved in the translating event, and the relations among them. The translation archive is a discursive formation and a dynamic and organic composition. Particularly relevant to the articulation of the translator's archive, and specifically in relation to the context of the Americas, is Roberto González Echevarría's use of the notion in relation to myth as a theory of Latin American narrative (1990). González Echeverría sees the "archive" as a way to understand the relationship between fiction, discourse, and memory and, through this lens, investigates the Latin American novel as part

8. The notion of the "archive" was initially proposed by Michel Foucault in The Archaeology of Knowledge.

9. Some individual translator's archives are housed in libraries' special collections. There is a collection of Gregory Rabassa's materials at Boston University, for example, which includes Rabassa correspondence with various Latin American authors and editors as well as annotated drafts of his translations of Gabriel García Márquez's Cien años de soledad, José Lezama Lima's Paradiso, Julio Cortázar's Rayuela, and others. A very complete repository of archival documents of US translators, is the relatively recent collection of translators' manuscripts housed in the Lilly Library at the University of Indiana at Bloomington. 
of the textual economy, of the discursive totality of its particular historical and geopolitical specificity (1990, p. 8). In an attempt to situate and historicize Latin American narratives within larger socio-historical discourses, González Echavarría speaks of a Latin American archive in which literature is ingrained in larger discursive and ideological structures. More recently, and also in the context of the Americas, Diana Taylor (2003) has referred to the archive in her work about the role of writing and performance in building cultural identity and historical memory. ${ }^{10}$ In her articulation of aesthetic and political performances and practices as systems of knowing and transmitting knowledge, Taylor opposes the archive to the repertoire, assigning the archive exclusively to texts and narratives and referring to the repertoire as the space for embodied practices and performances (2005). Both González Echevarría and Taylor use the term strategically and grant it specificity so that it can account methodologically for their particular goal. Although different, their perspectives frame and contextualize the discussion on the archive in terms of hemispheric cultural production.

Translators' documents are part of the textual fabric in which translations are inscribed, as are translators' practices and theories of language. The documents of translators of Latin American literature are part of the textual economy of the Americas. However, besides being part of this larger conversation about cultural production and historical memory, the translator's archive has its own specificity. As an operational notion, the archive enables me to refer to this collection of texts and documents in relation to a translating subject. In turn, these documents enter in relation among themselves and with larger narratives and other forms of discourse. It is my assumption that these texts along with the translations themselves and the translators' biographies and histories form an archive of intellectual history. In contrast to Taylor's distinction between the (textual) archive and the (performative and embodied) repertoire (2003, p. 19), in the case of the translators' archive I prefer not to abide by this distinction in order to lend the concept extension and texture beyond the strictly

10. Other theorists have also incorporated the notion of the archive to their studies about cultural production and intellectual history. I am grateful to Joshua Price for the reference to Edward Said's use of the concept in Orientalism. 
textual, so as to involve the translator's lives and experiences. I observe the context in which translation is practiced as well as factors that overdetermine it. But this examination is also, in large part, an examination of translators' voices and self-understandings. It is also meant to give space to those voices. I investigate translators' life histories, the frameworks through which they view their role as agents of social and cultural production, and the vectors and intersections between translator's narratives and other narratives. This enables me to enter into the translator's discursive composition, observe visible arrangements and establish other, less explicit sets and modes of relation.

Viewing the archive both as a physical and as a symbolic space and engaging translator's works and their histories is a rich and productive exercise, but it also reveals the limitations of the archive itself. At first, when I began to work with literary translators' documents, I faced the methodological dilemma of taking their statements seriously whilst establishing a critical distance in order not to take them strictly at face value. The justification of the examination itself is clear. A call for such a move can be seen, for example, in Pascale Casanova's invitation to contemplate the "entire configuration" $(2004$, p. 3$)$ to which texts belong. According to Casanova, everything that is written, translated, published, theorized, commented upon, etc., all these things are "elements of a vast composition" (ibid.). As Casanova states, the singularity of individual literary works cannot be observed in isolation, for it "becomes manifest only against the background of the overall structure in which they take their place. Each work that is declared to be literary is a minute part of the immense 'combination constituted by the literary world as a whole" (ibid.; my italics). Thus, translators' documents have value inasmuch as they are part of this vast composition.

Even though Casanova aptly asserts that each work declared literary is but one part of an immense "combination" (rather than a totality in and of itself), her implicit belief in the feasibility of such a totalizing task is problematic. Looking at the translator's archive in particular, once it reveals its materiality, which is fundamentally fragmented and discontinuous, we realize the futility of any totalizing possibility. Translators' archives (in line with Michel Foucault's initial characterization of the archive) are fragmented and discontinuous. However, the productive space of 
the translator's archive emerges precisely within its dispersion, its chaotic, accidental nature with its materials as well as its erasures and silences. Admittedly random and fragmented, the archive nonetheless reveals the discursive network of translated narratives. As such, it sheds light not only on the translations themselves, but also on the larger spectrum of literature that becomes accessible through what Franco Moretti calls "distant readings" (2000, pp. 56-57), whereby texts, instead of being studied as concrete, individual works, undergo a process of deliberate reduction and abstraction, so they can be situated within larger mappings. ${ }^{11}$ Translation is thus seen as embedded with practices of interpretation and of the circulation of knowledge and narratives.

Despite its epistemological potential, in and of, itself the translator's archive may be seen as a limited interpreting apparatus. Thus, it would be better understood as a signifier, a potential construct, which is to be read in order to make sense of the modes of relation that constitute it. Foucault's notion of "subjugated knowledges" (Mignolo, 2000, p. 20) is fundamental to create a critical archive that goes beyond a chronological account or a sum of documents to include objects and subjects that may or may not be conventionally considered worth of epistemological enquiry. In his examination of the coloniality of knowledge, Walter Mignolo underscores Foucault's awareness of the "disparity" between "academic and disciplinary knowledge, on the one hand, and non academic and popular knowledge, on the other" (ibid.). As he points out, for Foucault what a genealogy does, as "the union of "erudite knowledge and local memories" is to:

entertain the claims to attention of local, discontinuous, disqualified, illegitimate knowledges against the claims of a unitary body of theory which would filter hierarchies and order them in the name of some true knowledge and some arbitrary idea of what constitutes a science and its objects. (ibid.)

11. Franco Moretti has offered "distant reading" as a way of taking the necessary critical distance from the text, or texts themselves, to understand larger mappings that reflect, problematize, and offer more complex ways of approaching what he views as the fundamentally unequal world of literature (2000, p. 56-57). 
Translators themselves and translators' statements have traditionally been subjugated and invisible subjects of knowledge according to conceptions of textuality and authorship that reify and sacralize authors and originals. Moreover, translator's statements (e.g., paratexts, marginalia) due to their informal, disperse form, are also subjugated objects of knowledge as they are not easily identifiable or conventionally considered objects worthy of scholarly investigation. It is to a great extent in this sense that the translator's archive is a rich basis for a genealogy, understood as the union of "erudite knowledge and local memories" (ibid.). Beyond the collection of the archive's elements, the genealogy focuses on the relations among these elements, which will in turn reveal the asymmetries of the translator's discursive formation and those its investigation can expose. Moreover, the translator's archive lends itself to a genealogy that focuses on the subjects who translate and places them in relation to their (textual, intellectual) production, rather than reducing them to it. The archive's diversity, its statements, documents, historical, social, and subjective markers are revealing symptoms of the heterogeneity and organicity of translation.

\section{Reading the Archives of Translators of Latin American Literature}

In my earlier work I looked at the case of US translator Gregory Rabassa, aiming to historicize and situate the role of translation and of Rabassa as a translating subject in the creation and circulation of Latin American literary narratives. Based on the present argument about what constitutes a translator's archive, I can now, in retrospect, describe that investigation of Rabassa's life and work as an attempt to a sociography that focused primarily on the translator's statements and on the reception and impact of his translations, an examination of his archive. ${ }^{12}$ Some of the aspects included on the examination of Rabassa's archive were his ideas about translation in general and about his own practice in particular as they can be traced in his writings (articles, prefaces, and other published and unpublished writings)

12. See Gregory Rabassa's Latin American Literature: A Translator's Visible Legacy (2010). An earlier discussion of the translator's views about his practice appeared in "Rabassa and the 'Narrow Act': Between Possibility and an Ethics of Doubt” (Guzmán, 2008). 
and his translator's memoir If This Be Treason: Translation and Its Dyscontents (Rabassa, 2005) as well as in interviews-including one I conducted. I was able to reflect on the conceptions of language and translation that underlie his statements. I was also able to consult materials, both published and unpublishedincluding documents in the Rabassa collection at the Howard Gotlieb Archival Research Center at Boston University-which revealed a great deal about the translator's relationship with authors, editors, and other agents of cultural production.

Looking at archival textual material, such as Rabassa's annotated manuscripts, shed light on the translation process and on the translator-author relationship and collaboration (in the case of Rabassa, especially with the Argentine writer Julio Cortázar). The examination of Rabassa's archive, which also included reviews and criticism about his translations, informed my discussion on the social and institutional aspects of his translation production and on various aspects conditioning the circulation and reception of his translations. This also allowed a reading of the historical significance of Rabassa's translations at the outset of the socalled Latin American literary Boom, of the Latin American literary canon as it began to take shape in the sixties, of the way North American (and to some extent, international) reception unfolded, and of the key role Rabassa played in the Boom's development. Finally, in a section of the project focusing on how Rabassa's translations related to larger narratives and discourses, the examination of his archive helped frame his work in relation to magical realism specifically, to the formation of the "virtual image" of Latin American literature internationally, and to the interplay of translation and hemispheric and world politics. ${ }^{13}$ This is particularly significant early in Rabassa's career: the first translations by Rabassa, including García Márquez's One Hundred Years of Solitude, where published against the backdrop of the cold war, and their production was conditioned by US cultural policy. The diverse materials that comprise Rabassa's archive allow for an understanding of his role as agent in the importation of writers (both mainstream and marginal, from Spanish America and Brazil) from the south to the north and of his legacy in the contemporary configuration of Latin American literature.

13. Virtual image is a term used by Brazilian translation theorist Heloisa Barbosa (see Guzmán, 2010, p. 118). 
After looking at Rabassa's case, I have also looked at the archives of other US translators of Latin American literature, such as Suzanne Jill Levine and Sergio Waisman. ${ }^{14}$ Looking at their archives alongside Rabassa's helped me outline a comparative scenario and a view of these translators as a collectivity. ${ }^{15}$ This comparative observation exposed the similarities and differences among these translators; it allowed me to see elements and patterns that are not necessarily visible in an individual translator's archive. I found, for instance, many common elements in the biographies of these three translators, specifically concerning their immigrant family histories. There are also common points when it comes to their practice specifically. Rabassa, Levine, and Waisman have translated living authors and have entered in relationships with them that go beyond sporadic consultation. Like in Rabassa's case, looking at Levine's and Waisman's archives also shed light on their relationships with the authors whose works they translated. Their social profile and status is very similar. The three are academics and, although they do not belong to a wealthy class, they are part of the US intelligentsia with its particular social specificity. Moreover, being affiliated with universities gives them certain institutional capital to support their translation activity. Translation, in turn, is central to their position as agents of northsouth literary exchange.

14. I have focused on Rabassa, Levine, and Weisman because of their position in the literary translation scene in the United States, with their translations of Latin American literature. Their translations are highly praised and circulate widely. Especially Rabassa, but also Levine, belong to the generation that translated and help form the so-called Latin American Boom of the 1970s. In the sixties, as the demand for translation of Latin American writing increased, they got involved, along with other translators, by translating Latin American works and also as agents, promoters, and commentators of these works. Scholars and writers such as Rabassa, Levine, and Waisman made crucial decisions about which works by which authors from Spanish American and Brazil would be translated. The choices made by these translators created a readership and an image of Latin American writing.

15. I present a more detailed comparative reading of the archives of Rabassa, Levine and Waisman in the article "Translating Latin America: Reading Translator's Archives" (Guzmán, 2012b), in which I include citations from their work. In the present article, and in the interest of its argument, I am only summarizing some of the findings to illustrate what the examination of several translators' archives may reveal. 
Looking at these translators' archives, I also found evidence of the relationship between translation and criticism in the work of these three translators. They write articles and reviews about translation and about Latin American fiction. In their reflections on their practice, these three translators coincide in a number of ways, such as in their resistance to the dogma of impossibility of translation-i.e., the perception, based on a sacralized view of the original, that translation is an inherently impossible task. ${ }^{16}$ They coincide in viewing translation as a creative, poetic task. However, there are marked differences in their views about texts, writing, and their own role as cultural agents. Some exhibit more romanticized views of literature and textuality, centered on aesthetic considerations, whereas others engage translation more politically, from a view of translation as socially situated and a consciousness that translation projects are part of larger social and personal projects. Rabassa, Levine and Waisman formulate the act of translation and their task according to their respective conceptual repertoire and also their individual commitments and investments. Their archives reveal the extent to which their views are inflected by theories and ideologies of language and culture.

The translator's archive is replete with productive tensions and contradictions. The elements of the archive-disperse, fragmented, discontinuous-reveal themselves as co-constitutive and interdependent when looking at the relations among them. The archives of Rabassa, Levine, and Waisman are part of a "vast discursive composition" within the realm of literary practices-which are, in turn, part of the larger spectrum of social practices-in the contemporary context, in which English is the language of global linguistic primacy and translation into English, as Michael Cronin affirms, "has become the most widely accepted means of symbolic exchange" (1998, p. 152). English translation gives way to new and potential readerships and is also a condition of possibility for translation into other languages. The work of Rabassa, Levine and Waisman, has had and will continue to have a spectrum of effects that cannot be separated from the socio-cultural circumstances that surround their practice. They belong to a collectivity of agents and forces that intervene for the translating event to be possible, whether or not the translators

16. I discuss this question in the first chapter of Gregory Rabassa's Latin American Literature: A Translator's Visible Legacy (Guzmán, 2010). 
themselves are aware of the economic and symbolic conditions of translation production.

Comparing translators' archives may reveal structural and symbolic asymmetries as well as alternatives to counter them. It can also illuminate a study of translation practices within unequal conditions of cultural production. As translated narratives are part of larger discursive and ideological configurations, the work of Rabassa, Levine and Waisman-like that of other US translators, and translators of Latin American literature into other languages - has produced and will continue to produce effects that exceed the territory of the literary as it is conventionally understood. As part of discursive relationships that reflect sociopolitical conditions, the diffusion of translated narratives generates new, organic recombinations. Viewing translators as agents in the Americas shows the inherently ambiguous role they play given their location and the interplay between selfconsciousness and the structural forces of hemispheric literary exchange.

\section{Conclusion}

The translator's archive can be interpreted from a variety of perspectives. ${ }^{17}$ Its epistemological potential will differ depending on the geopolitical specificity of the translator whose archive is being composed or interpreted, of any conceptual devices used to interpret it, and of any other variables and considerations that may condition its study. Translators' archives can shed light on

17. The ways in which the archive can be read, interpreted, or activated are multiple. In the article "Ángel Rama y la traducción como praxis y experiencia americana" (2013), I look at the role of translators in relation to the archive of Latin American cultural history from the perspective of the narrative analysis proposed by the Uruguayan cultural theorist Ángel Rama in La transculturación narrativa en América Latina (1982). Rama's work helps characterize the relations between translation and intellectual history, as he grounds his argument on a bidirectional understanding of the production of narratives with an accent on the south, positing translation as "transculturación" and as an experience of the Americas. In his articulation of a narrative transculturation, Rama identifies the notions of selectividad, concentración and reiteración (1982, pp. 194-198) for the analysis of narratives. Placing translation praxis within narrative praxis, this perspective can be applied to translated narratives as such, and as ideological objects or what Rama calls "epidermic translations" ("traducciones epidérmicas") of deeper mental workings and values (ibid., p. 9). 
translators' statements as a heterogeneous discursive formation. Moreover, since its examination can straddle and cross the boundaries across disciplines, the archive has transdisciplinary potential.

Given the social and cultural specificity of the phenomenon of translation of Latin American literature in North America, and following the imperative of placing the subject who translates at the center of enquiry, I feel compelled to investigate the figure of the translator multi-dimensionally. Through my investigations I have realized that I must establish a counterpoint between the individual and the collective. First, the translators of Latin American literature into English are, like other translators, cultural mediators, who embody the complex and at times uneasy position of mediating cultures and communities in asymmetric relations of power. Second, the translators of Latin American literature are part of a socially-determined collectivity whose performance is both conditioned by and constitutive of the aforementioned sociohistorical context-i.e., the political and institutional backdrop of the translatorly activity from the fifties on and into the twentyfirst century.

Conceptually, an examination of the translating self should be, by necessity, inclusive, for no single framework would account for the complexity of the subject who translates in its extension and its depth. This is due, to an extent, to the limits of individual approaches when it comes to articulating the interplay between the intimate and personal and the cultural and socio-historical. Simeoni's articulation of the agent of translation and his proposal for translators sociographies is a productive possibility for a study of the translator that underscores situatedness. A flexible approach to the translator's sociography provides a space to write about translators and translator's works in their individuality and also as cultural products and social agents including an investigation of the "theories" of language that inform the practice and on the translator's self-understanding. Translation is an act, a praxis, a performance, and a "cognitive operator" that allows for a focus on the subject within multiple realms. For the purpose of my particular project, it has allowed me to see relationships and differences in south-north translation within the spectrum of the Americas as a continuum with particular geopolitical and symbolic specificities. The translator's sociography can illuminate the relationships 
inherent to the translating event, the individuals or agents that participate in it, and the social and political circumstances that condition it. The notion of "habitus" applied to the translator reveals the translating event as socially-inflected and illuminates the social conditions under and within which translators operate and within which their subjectivity is constituted. Beyond strictly textual and aesthetic considerations, the habitus can be productively integrated with other notions for the articulation of the translator's image and self.

For a historiography of translators of Latin American literature, and to understand the texture and complexity of translation strategies, decisions, and life histories, it is imperative to look at each individual translator. Examining the translator's singularity gradually allows for a heterogeneous vision of a collectivity. The translator's archive unveils the critical perceptions the translators themselves have of their work, their views and their role within diverse landscapes of language and culture contact, and in the case of US translators of Latin American literature, of cultural exchanges in the Americas, i.e., of our cultural history. The multilayered image of translators that emerges from their archives generates a pluri-voiced vision of translation as a field of action. Extending from texts to experiences, the translator's archive reveals a view of translation as invested and embodied practice, rendering translators' bodies and life histories as part of the epistemological enquiry about the translator's self.

\section{References}

Baker, Mona (2006). Translation And Conflict: A Narrative Account. New York, Routledge.

Buzelin, Hélène (2007). "Translation Studies, Ethnography, and the Production of Knowledge." In P. St-Pierre and P.C. Kar, eds. Translation-Reflections, Refractions, Transformations. Amsterdam/ Philadelphia, John Benjamins, pp. 39-56.

Casanova, Pascale (2004). The World Republic of Letters. Trans.

M.B. DeBevoise. Cambridge, Harvard University Press.

Cronin, Michael (1998). "The Cracked Looking Glass of Servants.” The Translator, 4, pp. 145-162.

Foucault, Michel (1972). The Archaeology of Knowledge. Trans. A.M Sheridan Smith. New York, Routledge.

García Márquez, Gabriel (1970). One Hundred Years of Solitude. Trans. 
Gregory Rabassa. New York, Harper Collins.

González Echevarría, Roberto (1990). Myth and Archive: A Theory of Latin American Narrative. New York, Cambridge University Press.

Guzmán, María Constanza (2008). "Rabassa and the 'Narrow Act':

Between Possibility and an Ethics of Doubt.”TTR, 21, 1, pp. 211239.

Guzmán, María Constanza (2010). Gregory Rabassa's Latin American

Literature: A Translator's Visible Legacy. Lewisburg, Bucknell University Press.

Guzmán,María Constanza (2012a). "Jill Levine and the Spider Woman:

Translation as Biography.” In S. Ingram and M. Reisenleitner, eds.

Historical Textures of Translation: Traditions, Traumas, Transgressions.

Vienna, Mille Tre Verlag, pp. 151-162.

Guzmán, María Constanza (2012b). "Translating Latin America:

Reading Translator's Archives." In M. Feltrin-Morris and

D. Folaron, eds. Translation and Literary Studies: Homage to Marilyn

Gaddis Rose. Manchester, St. Jerome, pp. 90-100.

Guzmán, María Constanza (2013). "Ángel Rama y la traducción como praxis y experiencia americana." In I. Fenoglio, R. Díaz de la Sienra and M. Quijano, eds. La tradición teórico-critica en América Latina: mapas y perspectivas. México, Bonilla Artigas Editores, pp. 57-71.

Levine, Suzanne Jill (1991). The Subversive Scribe: Translating Latin American Fiction. Saint Paul, MN, Graywolf Press.

Mignolo, Walter (2000). Local Histories/Global Designs: Coloniality, Subaltern Knowledges and Border Thinking. Princeton, Princeton University Press.

Moretti, Franco (2000). “Conjectures on World Literature." New Left Review, 1, pp. 54-68

Rabassa, Gregory (2005). If This Be Treason: Translation and Its Dyscontents. New York, New Directions.

Rama, Ángel. (1982). Transculturación narrativa en América Latina. Buenos Aires, Siglo XXI.

Simeoni, Daniel (1995). "Translating and Studying Translation: The View from the Agent." Meta, XL, 3, pp. 445-60.

Simeoni,Daniel (1998). “The Pivotal Status of the Translator's Habitus.” Target, 10, 1, pp. 1-39.

Simeoni, Daniel (2007a). "Between Sociology and History: Method in Context and in Practice." In M. Wolf and A. Fukari, eds. Constructing a Sociology of Translation. Amsterdam/Philadelphia, John Benjamins, pp. 187-204.

Simeoni, Daniel (2007b). "Translation and Society: The Emergence 
of a Conceptual Relationship.” In P. St-Pierre and P. C. Kar, eds. Translation-Reflections, Refractions, Transformations. Amsterdam/ Philadelphia, John Benjamins, pp. 13-26.

Simeoni, Daniel (2008). "Norms and the State: the Geopolitics of Translation Theory." In. A. Pym, M. Shlesinger, D. Simeoni, eds. Beyond Descriptive Translation Studies: Investigations in Homage to Gideon Toury. Amsterdam/Philadelphia, John Benjamins, pp. 329339.

Taylor, Diana (2003). The Archive and the Repertoire: Performing Cultural Memory in the Americas. Durham, Duke University Press.

Waisman, Sergio (2005). Borges and Translation: The Irreverence of the Periphery. Lewisburg, Bucknell University Press.

Wolf, Michaela (2007). "Introduction: The Emergence of a Sociology of Translation." In M. Wolf and A. Fukari, eds. Constructing a Sociology of Translation. Amsterdam/Philadelphia, John Benjamins, pp. 1-36.

\section{María Constanza GUZMÁN}

School of Translation - Department of Hispanic Studies

Glendon College, York University 2275 Bayview Ave.

Toronto (Ontario) M4N 3M6

CANADA

mguzman@glendon.yorku.ca 